\title{
Mobile Learning Approaches and Its Impact on Student's Education - A Survey
}

\author{
Sadia Aziz, Rajan Kadel, Deepani B. Guruge, Krishna Paudel, and Vanaja Karagiannidis
}

\begin{abstract}
As mobile devices have become a part of our everyday life, there is a lot of research going on how to make this technology more productive for the students. Most of the research studies have indicated that, mobile devices are very useful for students while a few research studies negates its effectiveness. In this paper, we have presented the literature survey conducted on the use of mobile technologies in the field of Teaching and Learning (T\&L). These studies are broadly classified into three areas: Impact and learning environment; specific applications; and mobile learning framework. We will be exploring all these areas in this paper. Our review in impact and environment of mobile learning indicates that the use of mobile technology is nourishing the knowledge and learning of students in most cases. Our review on specific applications of mobile learning reveals positive impacts on learning in various fields but the key concern raised was difficulties in implementing them and not having proper control guideline. Moreover, our review on frameworks for mobile learning indicates that there are different frameworks developed for different applications. Most of the applications are limited to non-technical areas. However, we can observed that there is a lack of connectivity between course development and framework for mobile learning. Therefore, the future course developers need to address the gap by taking into account of learners' behavior in using mobile devices and their cultures to enrich student engagement and learning.
\end{abstract}

Index Terms-Application areas, learning environment, learning framework, learning impact, mobile learning.

\section{INTRODUCTION}

Over the past decade, it has been observed that the use of mobile devices is increasing and facilitating student's wireless connectivity towards learning [1]. Nielsen [2] on-line research study reports, the percentage of Australians who own a smart phone is highest, $98 \%$, in the age group $18-24$ and $97 \%$ in the age group 25-34. This survey result might reflect to international student on the mobile possession and this trend is increasing each year. Therefore, mobile learning technologies is a valuable addition to traditional learning techniques, as learners have the opportunity to participate in educational activities at any time and place [3].

Manuscript received March 12, 2021; revised June 3, 2021. This project is funded by MIT Scholarship of Teaching and Research Fund. We would like to thank MIT for providing administrative and financial supports.

Sadia Aziz, Rajan Kadel, Deepani B. Guruge, and Krishna Paudel are with School of IT and Engineering of Melbourne Institute of Technology, Australia (e-mail: saziz@mit.edu.au, rkadel@mit.edu.au, dguruge@mit.edu.au,kpaudel@academic.mit.edu.au).

Vanaja Karagiannidis is with School of Business Melbourne Institute of Technology, Australia (e-mail: vkaragiannidis@mit.edu.au).
The major use of these devices are for communication (such as video call, Short Message Service (SMS), email), web browsing, gaming and social media. It would be beneficial for all including education providers, educators and students if this resource can be used for better learning experience [4], [5].

Since smart phones and mobile Apps are getting popular, it strongly indicates that move from web based system to mobile friendly system may bring evolution in students' learning. Mobile Apps are easy to access than web-based applications under poor internet connection. Additionally, it also provides platform as a learning tools: quiz, gamification and game based learning, digital assessment tools and podcasts. Thus, there is enormous potential of using mobile learning in new generation for Teaching and Learning (T\&L). The move from traditional T\&L methods to web based T\&L methods has made a big difference on student's experience. This transformation has made a great impact on students' learning experience by saving their time and effort from non-productive tasks [5], [6]. The current web based tools like Moodle, Blackboard, Academic Management System, ZOOM and many others not only make the students' learning more interactive but also more apprehensive and comprehensive. The enhancement in technology has not stopped and one dimension of enhancement is, moving towards personalized T\&L. Mobile technology is one of them which leads students towards personalized learning [7]. Mobile technology will assist instant communications and feedback, learning anywhere and anytime and provide many more opportunities [8]. Therefore, there are many benefits and challenges using mobile technology in student learning. The mobile learning also provides additional comfort and convenience during COVID-19 period.

Mobile technology facilitates in classroom setting as well as learning in outdoors environment. In recent years, we have observed that mobile technologies in education have been discussed in several research studies in different perspective such as; monitor distractions affecting to cognitive functioning in demanding task-performance [9], [10], course and exam information provisioning [11], investigating ways to engage mathematics students in class [12], experimental study on designing and implementing mobile learning [13] and survey to recognise the values of mobile enabled education [14].

The remainder of the paper is organized as follows. Section II of the paper provides a brief overview on background of the mobile enabled education and discusses review objectives. Section III outlines the literature survey conducted to investigate how mobile technologies are applied in T\&L scenarios. Section IV presents the concluding 
remarks and future directions.

\section{BACKGROUND}

In today's higher education setting, Learning Management System (LMS) facilitates distant learning, blended-learning and e-learning by managing the learning resources. Nevertheless, many of the students and staff encounter challenges in using LMS effectively [15]. Most of the students find it difficult to access the web based applications when compared with mobile Apps as they live off campus and sometimes internet connectivity is poor. Therefore, there is a need to analyse in terms of resources such as mobile Apps and mobile technology friendly course structure for mobile learning.

This research study is part of the project at Melbourne Institute of Technology (MIT) to investigate the mobile learning approaches and ways in which these approaches can be focused to create positive impact on the students learning experiences. Mobile technologies play a major role in modern societies, especially on young student's daily activities. Widespread usage of mobile devices and technologies may have contributed to change the student's learning styles. Furthermore, the vast majority of international students work and travel during their study period and same applies to local students too. Additionally, mobile technologies can also assist student to access learning materials at their convenience and it also provides platform as a learning tools: quiz, gamification and game-based learning. Hence, mobile technologies may play a major role to create positive impact on students' learning experience. The aims of this review paper are:

- To investigate the impact of mobile technology on learning in different learning environment.

- To understand the current applications of mobile technology on learning.

- To recommend strategies or framework for future mobile learning in networking course.

\section{LITERATURE REVIEW}

In the current literature, there are several reviews on use of mobile technologies in T\&L scenarios [1], [16]-[18]. In [16], a review is conducted on trends on mobile technology assisted collaborative learning for journal publications. The reviewers indicate that mobile based collaborative learning is better than internet based collaborative learning in several aspects. The reviewers introduce a framework for collaborative mobile learning on their review findings.

In [1], the reviewers present critical analysis of the use of mobile devices in classroom. The key findings from the review has two sides. The negatives are mainly related with distraction produced by mobile devices in student engagement and student retention. The positive sides are innovative teaching methods and enhanced creativity and problem solving skills. Research Trends in mobile learning in higher education is presented in [17]. In [19], the paper outlines guidelines for implementing the mobile technologies for enhancing the e-learning environment. The mobile technologies provide the best environment for e-learning but there are challenges for effective implementation.

The key motivations for this paper is to review the literature in mobile learning in $\mathrm{T} \& \mathrm{~L}$ scenarios in three aspects: Impact and learning environment; specific applications; and mobile learning framework.

\section{A. Impact and Learning Environment}

In this section we are going to present a review on impact of mobile technologies on student's learning in different learning environments. First, we describe the meaning of impact and learning environments. Impact on student on the use of mobile devices in the learning could be positive and negative. Positive impact means mobile technology is very helpful or productive for students and negative impact means the use of mobile technology is diverting the concentration of students from studies and overall the experience and outcome is not productive. Learning environments considers the scenarios where the mobile technology used. There are two basic type of learning environments: Inside classroom and outside classroom. Inside class room refer to learning using face to face and class room environment. Outside classroom have very wide range of environments. Outside the classroom could be a distant learning scenario or a partially e-learning scenario. In distant learning scenario all the learning is online through internet and in partially e-learning scenario you can have some part of learning inside the class and rest of the part (quizzes, assignments, and exams) outside the classroom.

Most of studies showed positive impact [20]-[25] whereas a few showed negative impact [26], [27] while one research shows mixed impact [28]. According to [20], there are two types of teachers, innovative teachers and instrumental teachers. Innovative teachers attempt to shift from a teacher centered to a learning-centered approach while instrumental teachers believes in their traditional style of teaching. Chen and deNoyelles have shown that having a clearer understanding of students' mobile practices encourage universities to implement more student-centered support. Students preferred using mobile phones for learning outside classrooms and the use of mobile technologies among college students is increasing dramatically [25].

A comprehensive review on 'the use of portable technology to support curriculum learning in the classroom, and the use of personal mobile technologies for learning on the move' has been given in [21]. According to finding of this study, it has reported that there is increase on the student's interest in learning in turn improved their overall performance. The result of the study clearly identified that the use of mobile technology has increased the student's performance significantly [20], [21], [25].

In [22], the authors claim that students' intentional and active use of smartphones for educational purposes will increase their productivity and effective use of time. The authors argued that these factors can lead to greater out-of-class involvement and increased learning. In [23], the authors claim that m-learning have place in mainstream education and learning, and offering choices to learners will be beneficial for educational providers as well. Teachers will have new role to manage learning rather than delivery that 
will help learners gain required specific knowledge and skill in less time. Another aspect of importance of mobile technology in $\mathrm{T} \& \mathrm{~L}$ is providing new learning environment. In [24], Kukulska-Hulme et al. highlighted the effectiveness of mobile technology from learning environment perspective. The paper stated that mobile technologies can develop a collaborative learning environment that is necessary especially in the case when there are students with different background and languages. The key factors that help to build collaborative environment for flexible use, continuous use, instant feedback, penalization, socialization, and active interactive participation. So, one of the drawbacks of the mobile learning is that the use of mobile learning decreases combined studies, face to face interaction among students.

Some studies have found detrimental impact of using mobile technologies in T\&L [26], [27]. The study in [26] indicated that smart phones could be detrimental to learning. Froese et al. have studied the effect of cell phone use on learning and found that texting disrupts classroom learning [27]. The students' expectation of amount of disruption was found to be more than actual disruption which showed that it can lead to the poor performance of even good students.

In [28], the paper present mixed impact results while using mobile learning. The right use of mobile inside the class rooms and outside the class room can work not only to improve their performance but also can have a positive impact on their collaborative studies. Some challenges have also been discussed but the benefits over-weigh the challenges. Beside, this paper has made research in two domains: Collaborative environment and critical thinking. The research proved that for collaborative environment where the eye contact and face to face interaction is very necessary and use of technology doesn't support that. For critical thinking, the author has divided the mobile technology into two parts: Mobile Phones and Laptops. In this study, the use of Laptop has been proved useful in student critical thinking and engagement while use of mobile phones was leading towards distraction [28].

Table I shows a summary of review on impact and environment on mobile learning. Our review finds that most of studies showed positive impact. There are some studies which shows negative effect but these studies are very few and negative impact weighs far less than positive impact. So, overall we can say that mobile technologies are playing vital positive role in student's good performance. Mostly, mobile technology proved useful in out of class scenario whether its distant learning or partially e-learning or on-go (leaning during travelling or in some other free time) learning in most of the studies.

\section{B. Specific Applications}

In this section, the review on the use of mobile technology in specific areas of applications are presented. The review is based on subject of study, category of audience, scope of use, and specific objective of the study, specific feature of the mobile technology used.

In [29], Janette R. et al. have explored the use of iPads by supervising doctors and third year students during their clerkship period and found that the technology enhanced just in time access to medical information and supported evidence based decision making. Because of this benefits the authors expect that use of mobile technology in clinical setting will continue to grow but caution that there are some challenges with regards to training and motivation to adapt new technology by the old generation.

According to Simon, instant messaging App like WhatsApp if used as support tools outside the class can bring positive improvements in students' learning [5]. WhatsApp was used as a communication tools to exchange academic content in $\mathrm{T} \& \mathrm{~L}$ of database course in teacher training as supplementary to the face to face class. The author suggests that despite the positive influence the timing of interaction and not to interfere with students' private life are some important points to consider for the success of the tools.

TABLE I: A SUMMARY ON IMPACT AND ENVIRONMENT OF MOBILE

\begin{tabular}{|c|c|c|c|}
\hline Ref (Yr) & Environment & $\begin{array}{l}\text { Educational Level } \\
\text { and Devices }\end{array}$ & Impact \\
\hline [20] (015) & Face to face & $\begin{array}{l}\text { Secondary } \\
\text { education and } \\
\text { Tablet }\end{array}$ & Positive \\
\hline [22] (016) & Out-of-class & $\begin{array}{l}\text { Higher education } \\
\text { and smart phones }\end{array}$ & Positive \\
\hline [23] (007) & Any & $\begin{array}{l}\text { All levels and all } \\
\text { mobile devices }\end{array}$ & Positive \\
\hline [24] (018) & $\begin{array}{l}\text { In-class and } \\
\text { out-of-class }\end{array}$ & $\begin{array}{l}\text { Language learning } \\
\text { and any mobile } \\
\text { device }\end{array}$ & Positive \\
\hline [25] (013) & Out-of-class & $\begin{array}{l}\text { Higher education } \\
\text { and tablets and } \\
\text { mobile } \\
\text { phones }\end{array}$ & $\begin{array}{l}\text { Positive } \\
\text { impact-exploring } \\
\text { options }\end{array}$ \\
\hline [21] (013) & Any & $\begin{array}{l}\text { All levels and all } \\
\text { mobile devices }\end{array}$ & $\begin{array}{l}\text { Positive } \\
\text { with some } \\
\text { challenges }\end{array}$ \\
\hline [28] (017) & Both & $\begin{array}{l}\text { Secondary } \\
\text { education } \\
\text { Mobile Phones and } \\
\text { Laptops }\end{array}$ & $\begin{array}{l}\text { Positive and } \\
\text { Negative both }\end{array}$ \\
\hline [26] (015) & Face to face & $\begin{array}{l}\text { Higher education, } \\
\text { IPhone }\end{array}$ & Negative \\
\hline [27] (012) & In-class & $\begin{array}{l}\text { Cell phones and all } \\
\text { level }\end{array}$ & Negative \\
\hline
\end{tabular}

Kim et al. suggested that mobile technology can provide new learning experiences [30] for student outside the classroom for Teaching English to Speakers of Other Languages (TESOL). Student can engage more frequently in learning activities outside of the classroom and provide more learning opportunities in their community. But the use of mobile device as a learning tools depends upon the relationship between students and technology. Technology Adopter Category Index (TACI) score is one of the measure of the relationship.

Mtega et al. in [31] have presented the case of Sokodine University of Agriculture on the use of mobile phones in T\&L in Tanzania and found that though both teaching staff and students used it during the learning process but the use differed widely in terms of type of application. Text messages and calls are most commonly used but advanced learning application were not common. Application support, user's know-how, cost, mobile storage limitation were 
among the barriers for using advanced mobile applications.

\begin{tabular}{|c|c|c|}
\hline $\operatorname{Ref}(\mathrm{Yr})$ & Environment & Primary Purpose of use \\
\hline [29] (016) & $\begin{array}{l}\text { On the job medi- } \\
\text { cal training }\end{array}$ & $\begin{array}{l}\text { Access just in time medical } \\
\text { information and evidence based } \\
\text { decision making using iPad }\end{array}$ \\
\hline [5] (016) & $\begin{array}{l}\text { Outside school } \\
\text { hour-Teacher } \\
\text { training }\end{array}$ & $\begin{array}{l}\text { Instant messaging tools } \\
\text { (WhatsApp) to supplement } \\
\text { regular class }\end{array}$ \\
\hline [30] (013) & Out-of-class & Language learning eg TESOL) \\
\hline [31] (012) & $\begin{array}{l}\text { Higher Learning } \\
\text { institution } \\
\text { (Agriculture) }\end{array}$ & Mobile phone in T\&L Process \\
\hline [32] (013) & $\begin{array}{l}\text { Product design } \\
\text { course }\end{array}$ & mobile blogging \\
\hline [33] (007) & Distance learning & $\begin{array}{l}\text { improve student retention by } \\
\text { better support system using } \\
\text { mobile technology }\end{array}$ \\
\hline [34] (015) & $\begin{array}{l}\text { Problem based } \\
\text { Learning }\end{array}$ & $\begin{array}{l}\text { access information before } \\
\text { discussion and record keeping }\end{array}$ \\
\hline [35] (016) & $\begin{array}{l}\text { Deaf/Hard-ToHear } \\
\text { student }\end{array}$ & Math Learning \\
\hline [36] (009) & $\begin{array}{l}\text { Pedagogy in } \\
\text { higher education }\end{array}$ & knowledge dissemination \\
\hline
\end{tabular}

Herrington et al. in [36] finds that Information and Communication Technology (ICT) tools are mostly used in universities as medium of knowledge dissemination rather than as cognitive tools. The authors have endeavored to explore the pedagogical use of dormant but powerful mobile devices and presented means to formally put them in higher learning guided by two major learning frameworks named authentic learning and action learning that emphasize group collaboration to create further knowledge and understanding.

Fozdar et al. in [33] have found that mobile technology is an effective tools which can improve communication and learning. The authors suggested that SMS based mobile technology can be used to support and improve student retention.

Cochrane et al. in [32] have investigated the effect of mobile web 2.0 on the pedagogical development for the Bachelor of Product Design course and found that it produce better student engagement, flexibility of learning contexts, quality of student moblogging. The authors suggested that sustainability of mlearning depends on the institutional cultural and strategy shift from pedagogy to heutagogy and paradigm shift on behalf of lecturers into assessment and formative feedback, adaptation, selection of pertinent tools etc.

In [34], the authors have discussed how to best use mobile devices for Problem Based Learning (PBL) classes. If mobile devices are not used properly, they may not be effective rather it may be counterproductive. Student should be careful not to over-depend on mobile device, not to get distracted from learning. Similarly, over reliance on mobile device also prevents critical thinking and collaborative learning. Best approach suggested is to allocate fixed time for using the device for background information collection and not to use mobile devices during discussion and critical thinking.

In [35] Shelton et al. discusses the perspectives of teachers and students in math class in deaf/Hard-To-Hear (DTH) context and outlines the recommendation to the educational technology designers emphasizing the need to relate classroom teachers and students through the mobile App. According to the author, the use of mobile technologies in this learning contexts shows optimistic result.

Table II illustrates the diverse applications and environment. The review shows positive impact in various aspects of T\&L. However, proper control guideline of usage in terms of time, duration and purpose is necessary to achieve expected result. Additionally, change in content design and pedagogical approach to suit the mobile technology are challenge for the future.

\section{Frameworks}

The use of technologies in T\&L needs proper analysis of design requirement and followed by suitable model or framework to implement in order to achieve student learning outcomes. In this section, we are going to present a review on framework and model used in mobile learning environment.

Parsons et al. outlines key design requirements, opportunities and challenges associated with mobile learning environment [37]. The paper introduced metaphor-based design framework to meet all those design requirements. The proposed framework follows four steps: generic mobile environment issues, mobile learning context issues, learning experience and learning objectives. Those steps have several parameters and are categorized into individual learning and collective learning. Finally, the proposed framework is validated in four learning environments: Ambient wood project; Thinking tags project; Teacher training project; and Mobile helper project. However, the authors agreed that the framework has not been thoroughly accessed and further work is expected.

Lai et al. discussed formal and informal learning and followed by blended learning that combines formal and informal learning using mobile technologies where focus is made on demonstrating collaboration, coordination and communications [4]. The paper outlined Mobile-Blended Collaborative Learning (MBCL) model where the authors conceptualize the use of mobile technologies and applications to connect formal (classroom setting) and informal learning (community based setting). The paper also outlines tools that may be used for collaboration, coordination and communications. However, there is no validation of the model in mobile learning context.

Cobcroft et al. have focused on the mobile learning framework's key requirements including changes in learning and teaching landscape, technology, institutional setting and social networking setting [38]. The authors claims that the mobile learning framework should exploit the capabilities of mobile technology and mobility. Cobcroft et al. reviewed many existing frameworks and identified the key areas which requires focus for enhancing the usability of mobile technology in student's experience. 
Looi et al. outlined potential use of seamless learning environment for mobile learning [39]. The proposed framework transforms the paradigm from traditional learning to mobile learning combining formal and informal learning. For achieving this transformation, the authors highlighted the steps which are needed to be taken as, professional developments of teachers, designing the lessons according to new technology, and motivating the students productively in using devices.

The framework of blended mobility is a combination of blended learning and mobility learning, that adds value to blend learning pedagogy where students use the technological device where they access, iPods, iPad, PCs, $\mathrm{Mp} 3 \mathrm{~s}$, and Mp4s, among others [40]. Blended learning has turned out to be prominent among the most known approaches to educate English as Foreign Language (EFL). In [41], the authors outline M-learning framework based on three key aspects: technical, cultural and theoretical aspects. The validation of the framework is conducted by questionnaires with students but there is a lack of clarity on the validation process and applied areas of learning.

TABLE III: A SUMMARY ON FRAMEWORKS OF MOBILE LEARNING

\begin{tabular}{|c|c|c|}
\hline $\operatorname{Ref}(\mathrm{Yr})$ & Framework / Model & Applications areas \\
\hline [37] (007) & $\begin{array}{l}\text { Metaphor-based mobile } \\
\text { learning }\end{array}$ & $\begin{array}{l}\text { Applied in four specific } \\
\text { learning scenarios }\end{array}$ \\
\hline [4] (013) & $\begin{array}{l}\text { Mobile-Blended } \\
\text { Collaborative Learning } \\
\text { (MBCL) }\end{array}$ & $\begin{array}{l}\text { Formal and informal class } \\
\text { room }\end{array}$ \\
\hline [38] (006) & $\begin{array}{l}\text { Enhancing usability of } \\
\text { mobile learning }\end{array}$ & Not specific to any areas \\
\hline [39] (010) & $\begin{array}{l}\text { Seamless learning } \\
\text { framework }\end{array}$ & Not specific to any areas \\
\hline [40] (019) & $\begin{array}{l}\text { Blended learning mobility } \\
\text { approach }\end{array}$ & $\begin{array}{l}\text { English as Foreign } \\
\text { Language (EFL) }\end{array}$ \\
\hline [41] (017) & $\begin{array}{l}\text { Mobile learning } \\
\text { framework }\end{array}$ & Higher education \\
\hline [42] (012) & $\begin{array}{l}\text { Generic discussion and } \\
\text { review on framework }\end{array}$ & Not specific to any areas \\
\hline [43] (007) & $\begin{array}{l}\text { M-learning framework } \\
\text { based on mobile } \\
\text { connectivity and e- } \\
\text { learning }\end{array}$ & $\begin{array}{l}\text { Online and on campus } \\
\text { classroom }\end{array}$ \\
\hline [44] (017) & $\begin{array}{l}\text { Online learning design } \\
\text { aspects }\end{array}$ & $\begin{array}{l}\text { Distance education } \\
\text { specific to TESOL }\end{array}$ \\
\hline
\end{tabular}

In [42], the paper focuses on proving how mobile technologies are important in student learning process. Additionally, this paper also provides a design to transform the the traditional learning content into mobile based learning content. This paper also summarizes other similar projects that have been done in the same university. The author explains the challenges faced for the implementation of the design as the nature of learning environment was very much different and that made this transfer really hard to comprehend. The authors claim that the overall success of all the projects lead towards an effective mobile learning environment. However, there is lack of evidence and support for the claim.

In [43], the authors introduce a mobile learning framework based on mobile connectivity and e-learning. The framework uses m-learning applications that supports personalised and collaborative learning. The framework is evaluated using student survey questionnaires for classroom and online environments.

In [44], the authors analysed how students use technology for learning process and followed by design aspect of online learning environment. The design of online learning should be based on students' usage behavior of mobile phone, course materials should be based on mobile usage practices and time availability. Table III illustrates a summary of review on frameworks used or proposed for mobile learning. The review indicates that there is a specific model or framework for specific application in most cases and mainly frameworks and models are focused on non technical areas. Therefore, there is no model or framework which can be directly adapted for computer networking course. Next, we need to design and implement a framework for mobile learning that is suitable for the course.

\section{CONClusions And Future Directions}

This paper apprises findings of the research study conducted on mobile learning approach that enabled education in three different areas: impact and environment; specific applications and framework /model. Most of the studies indicated that mobile learning makes a positive impact on student learning experience for all learning environments. The review on mobile learning to specific applications indicates that mobile learning can be applied to various learning areas resulting in positive impacts and each application has its specific requirements and flexibility. Furthermore, our review on mobile learning framework finds that the proposed frameworks are very specific to particular applications.

Since we are in the first generation of the mobile enabled education, future research needs to focus on developing suitable mobile applications / mobile learning frameworks that consider learners' mobile device using behaviour, cultures and local contexts to enrich the student engagement while minimising distractions. Additionally, the course design and development should be initiated considering mobile learning contexts and environments. Our review indicates that there is a gap in course development framework or model for mobile learning. The framework should cover complete process from course development to implementation in order to enable mobile learning. Therefore, we believe that the future framework or model should emphasize with course development in a unified framework. Using mobile learning seems more prevalent at this pandemic COVID-19 period which increases importance for learning or social interaction for future research.

\section{CONFLICT OF INTEREST}

The authors declare no conflict of interest.

\section{AUTHOR CONTRIBUTIONS}

Vanaja Karagiannidis contributed on Section I. Rajan Kadel and Deepani B. Guruge contributed on Section I, Section II and Section IV. Sadia Aziz, Rajan Kadel and 
Krishna Paudel contributed in Section III. Sadia Aziz contributed on draft manuscript preparation. All authors reviewed the paper and approved the final version of the manuscript

\section{ACKNOWLEDGMENT}

This project is funded by MIT Scholarship of Teaching and Research Fund. We would like to thank MIT for providing administrative and financial supports.

\section{REFERENCES}

[1] L. F. M. G. Pedro, C. M. M. O. Barbosa, and C. M. N. Santos, "A critical review of mobile learning integration in formal educational contexts," International Journal of Educational Technology in Higher Education, vol. 15, no. 1, p. 10, 2018.

[2] Nielsen. (2016). Millennials are top Smartphone users. [Online]. Available:

https://www.nielsen.com/us/en/insights/article/2016/millennials-are-to p-smartphone-users/

[3] M. Kuimova, D. Burleigh, H. Uzunboylu, and R. Bazhenov, "Positive effects of mobile learning on foreign language learning," TEM Journal, vol. 7, no. 4, pp. 837-841, 2018.

[4] K.-W. Lai, F. Khaddage, and G. Knezek, "Blending student technology experiences in formal and informal learning," Journal of Computer Assisted Learning, vol. 29, no. 5, pp. 414-425, 2013.

[5] S. So, "Mobile instant messaging support for teaching and learning in higher education," The Internet and Higher Education, vol. 31, pp. 32-42, 2016

[6] L. Naismith, P. Lonsdale, G. Vavoula, M. Sharples, and N. F. Series, Literature Review in Mobile Technologies and Learning, 2004.

[7] H. Peng, S. Ma, and J. M. Spector, "Personalized adaptive learning: An emerging pedagogical approach enabled by a smart learning environment," Foundations and Trends in Smart Learning, pp. 171-176, Springer, 2019.

[8] Y. Mehdipour, H. Zerehkafi et al., "Mobile learning for education: Benefits and challenges," International Journal of Computational Engineering Research, vol. 3, no. 6, pp. 93-101, 2013.

[9] B. Thornton, A. Faires, M. Robbins, and E. Rollins, "The mere presence of a cell phone may be distracting," Social Psychology, 2014

[10] H. H. Wilmer, L. E. Sherman, and J. M. Chein, "Smartphones and cognition: A review of research exploring the links between mobile technology habits and cognitive functioning," Frontiers in Psychology, vol. 8, p. 605, 2017.

[11] A. Lorensuhewa, D. Guruge, T. Ilayperuma, and T. Ranjana, "A framework for developing sms and web-based application to provide valueadded services to the university community," Science Symposium, 2012.

[12] F. Martin and J. Ertzberger, "Here and now mobile learning: An experimental study on the use of mobile technology," Computers \& Education, vol. 68, pp. 76-85, 2013.

[13] H. Sheng, K. Siau, and F. F.-H. Nah, "Understanding the values of mobile technology in education: A value-focused thinking approach," ACM SIGMIS Database: The DATABASE for Advances in Information Systems, vol. 41, no. 2, pp. 25-44, 2010.

[14] J. Uziak, M. T. Oladiran, E. Lorencowicz, and K. Becker, "Students' and instructor's perspective on the use of blackboard platform for delivering an engineering course," The Electronic Journal of e-Learning, vol. 16, no. 1, p. 1, 2018.

[15] Q.-K. Fu and G.-J. Hwang, "Trends in mobile technology-supported collaborative learning: A systematic review of journal publications from 2007 to 2016," Computers \& Education, vol. 119, pp. 129-143, 2018.

[16] G. Krull and J. M. Duart, "Research trends in mobile learning in higher education: A systematic review of articles (2011-2015)," International Review of Research in Open and Distributed Learning, vol. 18, 2017.

[17] B. Eschenbrenner and F. F.-H. Nah, "Mobile technology in education: uses and benefits," International Journal of Mobile Learning and Organisation, vol. 1, no. 2, pp. 159-183, 2007.

[18] K.-W. Chuang, "Mobile technologies enhance the e-learning opportunity," American Journal of Business Education, vol. 2, no. 9, pp. 49-54, 2009.

[19] H. Montrieux, R. Vanderlinde, T. Schellens, and L. Marez, "Teaching and learning with mobile technology: A qualitative explorative study about the introduction of tablet devices in secondary education," PloS One, vol. 10, no. 12, p. e0144008, 2015.

[20] M. Sharples, "Mobile learning: Research, practice and challenges," Distance Education in China, vol. 3, no. 5, pp. 5-11, 2013.

[21] X. Liu, N. F. Burroughs, Q. Tian, V. L. Harvey, T. H. Housel, and N. Wellingon, "The impact of smartphone educational use on student connectedness and out-of-class involvement," Electronic Journal of Communication, vol. 26, no. 3-4, 2016.

[22] K. Peters, "M-learning: Positioning educators for a mobile, connected future," The International Review of Research in Open and Distributed Learning, vol. 8, no. 2, 2007.

[23] A. Kukulska-Hulme and O. Viberg, "Mobile collaborative language learning: State of the art," British Journal of Educational Technology, vol. 49, no. 2, pp. 207-218, 2018.

[24] B. Chen and A. Denoyelles, "Exploring students' mobile learning practices in higher education," Educause Review, vol. 7, 2013.

[25] C. C. Tossell, P. Kortum, C. Shepard, A. Rahmati, and L. Zhong, "You can lead a horse to water but you cannot make him learn: Smartphone use in higher education," British Journal of Educational Technology, vol. 46, no. 4, pp. 713-724, 2015.

[26] A. D. Froese, C. N. Carpenter, D. A. Inman, J. R. Schooley, R. B. Barnes, P. W. Brecht, and J. D. Chacon, "Effects of classroom cell phone use on expected and actual learning," College Student Journal, vol. 46, no. 2, pp. 323-332, 2012.

[27] H. Heflin, J. Shewmaker, and J. Nguyen, "Impact of mobile technology on student attitudes, engagement, and learning," Computers \& Education, vol. 107, pp. 91-99, 2017.

[28] J. R. Hill, M. A. Nuss, R. M. Cervero, J. K. Gaines, and B. Middendorf, "Enhancing third-year medical clerkships: Using mobile technology for teaching and learning," International Association for Development of the Information Society, 2016.

[29] D. Kim, D. Rueckert, D.-J. Kim, and D. Seo, “Students' perceptions and experiences of mobile learning," Language Learning \& Technology, vol. 17, no. 3, pp. 52-73, 2013.

[30] W. P. Mtega, R. Bernard, A. C. Msungu, and R. Sanare, "Using mobile phones for teaching and learning purposes in higher learning institutions: The case of Sokoine University of Agriculture in Tanzania," 2012.

[31] T. D. Cochrane, "Exploring mobile learning success factors," Alt-j, vol. 18, no. 2, pp. 133-148, 2010.

[32] B. I. Fozdar and L. S. Kumar, "Mobile learning and student retention," International Review of Research in Open and Distance Learning, vol. 8, no. 2, pp. 1-18, 2007.

[33] L. K. Chan, S. M. Bridges, I. Doherty, M. L. Ng, J. Jin, N. Sharma, N. K. Chan, and H. Y. Y. Lai, A Qualitative Study on How Health.

[34] Professional students and their PBL facilitators perceive the use of mobile devices during PBL, Interdisciplinary Journal of ProblemBased Learning, vol. 9, no. 1, p. 12, 2015.

[35] B. E. Shelton and M. A. Parlin, "Teaching math to deaf/Hard-of-Hearing (DHH) children using mobile games: outcomes with student and teacher perspectives," International Journal of Mobile and Blended Learning (IJMBL), vol. 8, no. 1, pp. 1-17, 2016.

[36] J. Herrington, A. Herrington, J. Mantei, I. Olney, and B. Ferry, "Using mobile technologies to develop new ways of teaching and learning," University of Wollongong, 2009.

[37] D. Parsons, H. Ryu, and M. Cranshaw, "A design requirements framework for mobile learning environments," $J C P$, vol. 2, no. 4, pp. $1-8,2007$.

[38] R. S. Cobcroft, S. J. Towers, J. E. Smith, and A. Bruns, "Mobile learning in review: Opportunities and challenges for learners, teachers, and institutions," 2006.

[39] C.-K. Looi, P. Seow, B. Zhang, H.-J. So, W. Chen, and L.-H. Wong, "Leveraging mobile technology for sustainable seamless learning: A research agenda," British Journal of Educational Technology, vol. 41, no. 2, pp. 154-169, 2010.

[40] M. I. Ghareb and S. A. Mohammed, "Blended learning mobility approach and english language learning," UHD Journal of Science and Technology, vol. 3, no. 2, pp. 1-9, 2019.

[41] A. M. Ahmed and M. I. Ghareb, "Design a mobile learning framework for students in higher education," Journal of University of Human Development, vol. 3, no. 1, pp. 288-296, 2017.

[42] M. Sarrab, L. Elgamel, and H. Aldabbas, "Mobile learning (m-learning) and educational environments," International Journal of Distributed and Parallel Systems, vol. 3, no. 4, p. 31, 2012.

[43] L. F. Motiwalla, "Mobile learning: A framework and evaluation," Computers \& Education, vol. 49, no. 3, pp. 581-596, 2007.

[44] O. Viberg and A. G onlund, 'Understanding students' learning practices: Challenges for design and integration of mobile technology 
into distance education," Learning, Media and Technology, vol. 42, no. 3, pp. 357-377, 2017.

Copyright $\odot 2021$ by the authors. This is an open access article distributed under the Creative Commons Attribution License which permits unrestricted use, distribution, and reproduction in any medium, provided the original work is properly cited (CC BY 4.0).

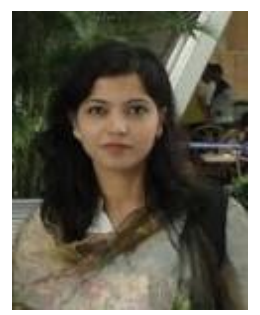

Sadia Aziz has over thirteen years of academic experience in teaching, research and supervision. She received her $\mathrm{Ph} . \mathrm{D}$ degree in computer engineering in 2007 from Wuhan University of Technology, Wuhan, China, in 2007. She worked in King Faisal University of Saudi Arabia as assistant professor for six years and played a significant role in curriculum development, examination management, and infrastructure management. She worked in CASE (Centre for Advanced studies in Engineering) in Pakistan for almost five years where she was leading two wireless network research groups.

Currently, she holds position of lecturer at School of Information Technology and Engineering (SITE), Melbourne Institute of Technology (MIT), Melbourne, Australia. Her research interests are wireless communications and networking, mobile ad hoc networks, QoS and reliability in real time systems, distributed system design, and teaching and learning. She possesses some prestigious professional certifications and has authored numerous refereed publications.

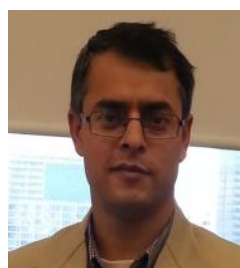

Rajan Kadel was born in Chitwan, Nepal. He received the B.Eng. degree in computer engineering from the Tribhuvan University, Kathmandu, Nepal, in 2002, the M.Sc. degree in telecommunications engineering from the University of Gavle, G" avle, Sweden, in 2007, and the $\mathrm{PhD}$ Degree in telecommunications engineering from the University of South Australia (UniSA), Adelaide, Australia, in

2013.

Currently, he holds position of senior lecturer and course coordinator at SITE, MIT, Melbourne, Australia. He has more than a decade of teaching, research and professional experience. Previously, he worked for telecommunication sectors in different capacities. He worked as an switching supervisor for Nepal Telecom and assistant manager Nepal Telecommunications Authority. His research interests cover game-based learning (GBL), gamification, recommender system, mobile learning, error-control coding, wireless sensor network (WSN), wireless body area network (WBAN).

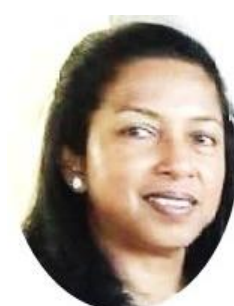

Deepani Guruge Deepani Guruge is a researcher with fifteen years of experience in teaching and conducting research in Australia and well as in Sri Lanka. Deepani earned her PhD from Central Queensland University Australia in 2008. She also holds postgraduate diploma in Industrial mathematics and B.Sc (Honours) in computer science degrees. She taught master of data science courses at Monash University, RMIT University and Swinburne University. Currently she is a lecturer at Melbourne Institute of Technology (MIT) and conducting research on educational theory, game-based learning (GBL) and course recommender systems.

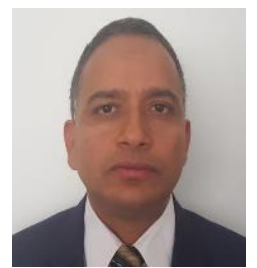

Krishna Paudel was born in Nepal. He received his M. Eng. degree in information and communication technologies from Asian Institute of Technologies (AIT), Bangkok, Thailand in 2007 and his B. Sc. engineering degree in electrical and electronics engineering from Bangladesh University of Engineering and Technology (BUET), Dhaka Bangladesh in 1995. He is currently a lecturer at School of Information Technology and Engineering (SITE), Melbourne Institute of Technology, Melbourne, Australia. His research interests include Game Based Learning, Gamification, assessment in mobile learning, data analysis and application of machine learning and Deep Learning techniques in engineering and physiological systems.

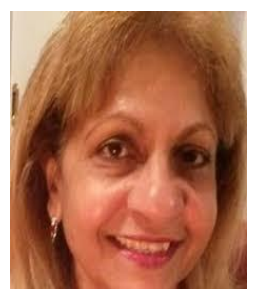

Vanaja Karagiannidis received her doctor of business administrations from Victoria University, Melbourne, Australia. Currently, she holds position of senior lecturer (management) at School of Business, MIT, Melbourne, Australia. 